\title{
Analisis Faktor Yang Mempengaruhi Persepsi Tentang Kondom Pada Kalangan Pria Beresiko Di Malang Jawa Timur
}

\author{
Riski Candra Karisma*), Zahroh Shaluhiyah**), Syamsulhuda BM **) \\ *) Akademi Kebidanan Wijaya Kusuma Malang Madiun \\ Korespondensi: qcanpearl@gmail.com \\ **) Magister Promosi Kesehatan Universitas Diponegoro Semarang
}

\begin{abstract}
ABSTRAK
Persepsi negatif tentang kondom akan menyebabkan perilaku pencegahan HIV-AIDS di kalangan pria beresiko akan rendah. Melekatnya persepsi kondom di masyarakat disebabkan oleh faktor eksternal, faktor personal internal serta gabungan antara keduanya. Penelitian ini dilakukan untuk mengetahui faktor yang berpengaruh persepsi tentang kondom pada kalangan pria beresiko. Jenis penelitian ini adalah explanatory research dengan pendekatan cross sectional. Responden dalam penelitian ini adalah pria beresiko yang berasal dari 4 jenis pekerjaan yaitu supir truk, supir taksi, buruh pabrik dan nelayan dengan jumlah responden 350 orang. Analisa bivariat menggunakan uji chi square dan analisa multivariate menggunakan regresi logistic. Hasil penelitian yaitu 11 variabel yang diteliti, terdapat 8 variabel yang berhubungan secara statistik dengan persepsi tentang kondom, yaitu variabel umur, pendidikan, pekerjaan, status perkawinan, pengalaman responden tentang kondom, sikap responden terhadap kondom, media informasi, pengalaman orang lain tentang kondom dan sosialisasi petugas kesehatan. Berdasarkan hasil uji multivariat menyatakan bahwa faktor paling berpengaruh adalah status perkawinan. KPA kabupaten dan kota Malang hendaknya menyediakan informasi rinci dan mudah dijangkau tentang kondom bagi kaum lelaki yang beresiko termasuk demonstrasi penggunaannya.
\end{abstract}

Kata kunci: Persepsi, Kondom, Pria Beresiko

\section{ABSTRACT}

Analysis of Factors Affecting Perceptions About Condoms At Risk Among Men In Malang, East Java; Negative perception about condoms would cause preventing HIVAIDS behavior among men that risked will be low.The cohering of condoms perception in society caused by a social factor (external), personal factors (internal) as well as a combination of both. This study aims to know the perception were the condoms that there are among the risked man in Malang East Java and the factors that influence the perceptions itself. Kind of this research is explanatory research with the cross sectional approach. Respondents in this research was man with the risk that come from four kinds of work that is a truck driver, cab drivers, factory workers people and fishermen, people with the number of respondents 350. Data analysis using univariat technique, bivariat by this chi-square multivariate and techniques with the logistic regression. The research result show that there is 11 variable that has been analyze, there are 8 statistically variable are associated with the perception of condoms, the age variables, education, work, marital status, respondents experience about condoms, the attitude of respondents about condoms, media information, experience others about condoms and socialization health workers. Based on the results of the multivariate stated that that is together impact on perception among the man condoms that risked in Malang is in marital status. KPA Malang district 
should provide detailed and easily accessible information about condoms for men who are at risk, including demonstration use.

Keywords: Perception, Condom, High Man risked

\section{PENDAHULUAN}

Perkembangan permasalahan

Human Immunodeficiency Virus (HIV) dan Acquired Immune Deficiency Syndrome (AIDS) semakin lama semakin mengkhawatirkan baik dari sisi kuantitatif maupun kualitatif. Tidak mengherankan bila permasalahan HIV dan AIDS telah menjadi epidemi di hampir 190 negara. Saat ini Indonesia sudah tidak lagi tergolong sebagai negara dengan prevalensi rendah, tapi sudah masuk ke epidemi terkonsentrasi dengan lebih dari $5 \%$ populasi tertentu di beberapa kota dan wilayah di Indonesia yang mengidap HIV (KPAN, 2013).

Bahkan di beberapa kota dan wilayah tertentu epidemik ini diperkirakan sudah masuk pada populasi umum. Indonesia termasuk salah satu negara di Asia yang mengalami epidemi HIV dan AIDS dengan prevalensi yang meningkat tajam dan belum menunjukkan penurunan.

Di Indonesia penyebaran HIV dan AIDS dari tahun ke tahun menunjukan peningkatan yang cepat, secara kumulatif jumlah kasus sampai dengan maret 2013 yaitu HIV sebanyak 103.759 dan AIDS sebanyak 43.347, dengan kematian sebanyak 8.340 (Apriani, 2011) dan jika 174 dilihat data 5 tahun yang lalu yaitu pada tahun 2007 jumlah kasus HIV sebanyak 5.904 dan AIDS 16.288, dengan kematian 2.287 (Ardana, 2008). Dengan peningkatan kasus yang sangat besar tersebut maka badan kesehatan dunia World Health Organization (WHO) memperingatkan Indonesia sebagai salah satu Negara Asia tercepat dalam hal peningkatan populasi HIV dan AIDS (Apriani, 2011)

Sedangkan salah satu isu yang saat ini berhubungan dunia kerja adalah meningkatnya kasus HIV/AIDS dimana lebih dari $90 \%$ dari mereka berusia produktif antara 20-50 tahun. Berdasarkan penelitian yang dilakukan International Labor Organization (ILO) tahun 2001, Population Mobility and HIV in Indonesia, pola dan kecenderungan penyebaran HIV terkait dengan perpindahan pekerja baik secara domestik maupun internasional. Meski belum diperoleh data memadai yang membuktikan adanya korelasi antara perpindahan pekerja dan penyebaran HIV, diasumsikan kelompok penduduk dengan mobilitas tinggi dan berperilaku seks berisiko, termasuk pekerja sektor pertambangan, konstruksi, perkebunan, 
transportasi, perikinan dan buruh migran rentan dengan penularan HIV (ILO, 2007)

Dikaitkan dengan survei yang dilakukan ILO (2004) dengan 1200 supir truk di Indonesia yang sering disebut Mobile Men with Money and Migrant diantaranya $47,5 \%$ pernah membeli seks, dimana rata-rata mereka membeli seks dari 8 pekerja seks setahun dan mempunyai 4 pasangan lain(ILO, 2007). Selain itu Penularan IMS kepada ibu rumah tangga terjadi melalui hubungan seks dengan suami yang kemungkinan besar merupakan pelanggan dari wanita penjaja seks. Saat ini, fenomena suami yang menjadi pelanggan dari WPS sangat banyak ditemukan. Salah satu kelompok yang bisaa menjadi pelanggan WPS adalah lelaki pekerja berpindah (mobile man) seperti supir truk, supir bus antarprovinsi, pelaut, pekerja konstruksi bahkan kalangan eksekutif yang sering bepergian ke luar kota (ILO, 2004)

Penelitian di Bali oleh Sumiarta menemukan bahwa 120 pengemudi truk trayek Denpasar-Surabaya sebagian besar (68 $\%$ ) sering mencari wanita penjaja seks di tempat-tempat peristirahatan selama dalam perjalanan. $87 \%$ dari mereka mempunyai kebisaaan berganti-ganti WPS, sedangkan sisanya mempunyai WPS langganan (Sutiyarsih, 2010). Di sepanjang tempat peristirahatan para awak truk ini terdapat wanita penjaja seksual (WPS) yang langsung maupun tidak langsung menawari transaksi seks kepada para awak truk ini. Permintaan dan penawaran sangat tinggi di area tersebut, sehingga isu perilaku seksual menjadi penting untuk disampaikan. Survei yang dilakukan oleh BPS dan Depkes pada kelompok ini ditahun 2007 mengeluarkan data bahwa 5\% awak truk ini mengidap IMS. Data ini merupakan kelompok profesi pekerja yang paling tinggi tingkat IMSnya dari kategori pekerjaan yang lain seperti, tenaga kerja bongkar muat (TKBM) di pelabuhan, anak buah kapal (ABK) dan lain-lain, khususnya untuk di pulau Jawa (Mudiharno, 1999).

Perilaku seksual beresiko yang dilakukan oleh lelaki pekerja berpindah ini ternyata tidak diimbangi dengan upaya pencegahan penularan HIV. Padahal, sebenarnya penularan HIV dapat dicegah salah satunya dengan penggunaan kondom. Dari data STBP tahun 2011 tentang data penggunaan kondom konsisten pada wanita penjaja seks langsung (WPSL) hanya mencapai 14\% pada tahun 2011, pada wanita penjaja seks tidak langsung (WPSTL) 26\% pada tahun 2011. Sedangkan prevalensi HIV pada WPS mencapai $10 \%$ pada tahun 2011 sedangkan pada pria beresiko (termasuk supir truk dan kernet truk) pemakaian kondom konsisten 
hanya 8\% pada tahun 2011 (STBP, 2011). Data Survielan Terpadu Biologis Perilaku HIV/IMS (STBP) tahun 2011 oleh Depkes dan BPS menunjuk tingginya kasus infeksi menular seksual (IMS) di kalangan sopir truk. Sopir truk menjadi kelompok yang paling rentan dibanding dengan kelompok pekerjaan lain dengan bahaya HIV dan AIDS (STBP, 2007).

Kelompok masyarakat yang diprioritaskan untuk berperan dalam pencegahan penularan HIV adalah kelompok yang berperilaku beresiko, diantaranya Wanita Pekerja Seksual (WPS) dan pengguna narkoba suntik. Akan tetapi berdasarkan penelitian Erdana (2004), sebagian besar WPS tidak mau menggunakan kondom sewaktu melakukan hubungan seksual. Hal ini dikarenakan pelanggan tidak menginginkan kondom. Kondom dianggap mengurangi kenikmatan dalam berhubungan seksual. Penggunaan kondom pada hubungan seksual yang beresiko cara yang paling efektif dalam pencegahan penularan HIV (Ardiningsih, 2013).

Kondom dianggap menjadi komponen penting dalam program pencegahan HIV. Penggunaan kondom pada perilaku beresiko menunjukkan keberhasilan dalam mengontrol penyebaran wabah HIV karena kondom adalah satu- satunya alat kontrasepsi yang dapat mencegah resiko penularan dari satu orang ke orang lain melalui hubungan seksual. Thailand dengan program 100\% kondom menargetkan pekerja seks sebagai alasan utama untuk menanggulangi penyebaran HIV Di lingkungan lain, peningkatan jumlah penggunaan kondom berkontribusi pada penurunan penyebaran HIV serta menunjukkan peran signifikan dalam perubahan tingkat penyebaran HIV (Aaron, 2013).

Tetapi di Indonesia sebagian besar masyarakat masih banyak persepsi negatif yang beredar di masyarakat tentang kondom. Berdasarkan penelitian yang dilakukan Komisi Penanggulangan Aids pada tahun 2009 didapatkan hasil bahwa pemuka agama ada yang berpendapat bahwa penggunaan kondom sebagai alat untk pencegahan HIV-AIDS dianggap sebagai pelegalan zina dan selain itu menganggap bahwa kondom tidak efektif dalam mencegah penularan HIV. Begitu halnya dengan pendapat dari anggota dewan, bahwa program kampanye kondom dinilainya justru berpotensi meningkatkan seks bebas di tengah masyarakat dan akan meningkatkan risiko penyakit lainnya. Seperti halnya pada bulan Desember tahun 2013 mahasiswa dan para pemuka agama bahkan memberikan sebutan kepada 
menteri kesehatan Republik Indonesia dengan gelar "Ratu Kondom" dikarenakan bahwa kebijakan melaksanakan Pekan Kondom Nasional (PKN) yang rencananya akan diselenggarakan pada hari AIDS sedunia dianggap tidak pada subtantif dari permasalahan terkait penanggulangan HIV/AIDS dan dianggap melegalkan seks bebas (Ardiningsih, N, 2013). Penggunaan kondom juga dianggap tidak efektif dalam mencegah penularan HIV dan AIDS. Selain itu pemahaman masyarakat terhadap fungsi kondom masih dinilai rendah. Anggapan negatif masih melekat pada kondom ketika alat tersebut beredar bebas di pasaran. Ada beberapa pendapat yang menilai jika kondom disediakan di supermarket dengan harga yang cukup murah, akan menggenjot jumlah perilaku seks bebas di kalangan anak muda yang belum sah menjadi pasangan suami istri secara hukum dan agama (Aaron, 2013).

Oleh karenanya, terciptalah persepsi negatif keberadaan kondom di suatu tempat yang artinya mendukung praktik prostitusi. Melekatnya persepsi kondom di masyarakat disebabkan oleh faktor sosial (eksternal), faktor personal (internal) serta gabungan antara keduanya. Penyebab pertama, persepsi sosial yaitu dengan membeli kondom seolah-olah merupakan buruk. Persepsi kedua yang membelenggu adalah persepsi personal yang lebih mengarah ke alasan pribadi, yaitu dengan memakai kondom hubungan seksual menjadi tidak nyaman. Sedangkan persepsi ke tiga merupakan gabungan antara faktor sosial dan faktor personal. Selain itu tingkat penggunaan kondom yang rendah disebabkan oleh lingkungan sosial yang masih belum sepenuhnya mendukung penggunaan kondom. Situasi ini membuat persepsi terhadap kondom akan terus ada didalam masyarakat (Aaron, 2013).

Kota Malang sebagai Kota pelajar, pariwisata dan industri dan kota terbesar kedua di Jawa Timur merupakan kota dengan tingkat urbanisasi yang tinggi dimana Kota Malang merupakan tempat tujuan masyarakat sekitar kota Malang dan bahkan dari luar pulau Jawa. Kondisi tersebut memberi peluang pada peningkatan urbanisasi penduduk sehingga mengakibatkan terjadinya ledakan penduduk. Meningkatnya kasus HIV di Kota Malang merupakan salah satu dampak dari berkembangnya kegiatan prostitusi yang merupakan konsekuensi logis dari kemajuan pembangunan dibidang pariwisata (Dinkes Kabupaten Malang, 2013).

Rendahnya pendidikan dan pengetahuan mereka ditambah dengan 
kurangnya keterampilan akan menempatkan mereka bekerja di sektor informal seperti halnya supir. Data dari Dinas Kesehatan (Dinkes) Kota Malang selama kurun waktu 2011 jumlah penderita HIV/AIDS sebanyak 2.021 orang dan tahun 2010 sebanyak 1.636 orang. Dari data tersebut penderita paling banyak adalah kaum laki-laki, yakni mencapai $65,71 \%$ dan perempuan $34,29 \%$. Sedangkan dari usia penderita, rata-rata 2549 tahun $(67,79 \%)$ dan selebihnya dari berbagai usia (Dinkes Kabupaten Malang, 2013). Data STBP 2011 menunjukkan, penggunaan kondom baru 14 persen. Padahal, prevalensi pekerja seks, baik lakilaki, perempuan, maupun waria, yang mengidap HIV tinggi, 7-20\%. di Kota Malang. Sedangkan pada pria dengan resiko tinggi di Kota Malang hanya 35\% yang menggunakan kondom konsisten pada seks komersial terakhir.

Berdasarkan permasalahan diatas persepsi tentang kondom dipengaruhi oleh faktor tertentu dilihat dari faktor internal dan faktor eksternal.

\section{METODE PENELITIAN}

Survey explanatory research digunakan dalam penelitian ini untuk menjelaskan hubungan antara variabel penelitian melalui pengujian hipotesa pada penelitian kemudian dilihat pengaruhnya.
Penelitian ini termasuk jenis penelitian kuantitatif yaitu menganalisis Analisis Faktor Yang Mempengaruhi Persepsi Tentang Kondom Pada Kalangan Pria Beresiko Di Malang Jawa Timur. Penelitian ini dilaksanakan dengan menggunakan pendekatan belah lintang (cross sectional) yaitu penelitian untuk mempelajari antara faktor resiko (variabel bebas) dengan faktor efek (variable terikat) dengan cara pengumpulan data dilakukan sekaligus pada satu saat (point time approach). Metode pengumpulan data primer menggunakan metode survey melalui kuesioner sebagai pedoman dalam wawancara terstruktur.

Populasi target di dalam penelitian ini terdiri dari beberapa sub populasi yaitu supir truk, supir taxi, buruh pabrik, dan nelayan di Malang Jawa Timur dengan jumlah keseluruhan populasi adalah 2.670 orang. Penghitungan jumlah sampel menggunakan rumus Slovin didapatkan sampel sejumlah 350 responden. Teknik pengambilan sampel menggunakan teknik purposive sampling yaitu berdasarkan penilaian (judgment) peneliti mengenai siapa-siapa saja yang pantas (memenuhi persyaratan) untuk dijadikan sampel dengan kriteria tertentu. Variabel terikat dalam penelitian ini adalah Persepsi positif/negatif tentang kodom dengan Variabel bebas adalah Karakteristik (umur, pendidikan, 
pendapatan, status perkawinan, pekerjaan); pengetahuan responden; pengalaman responden; sikap responden terhadap kondom; media informasi; pengalaman orang lain mengenai kondom; sosialisasi petugas kesehatan mengenai kondom. Hasil penelitian di analisis secara bivariat dan multivariat. Analisis bivariat digunakan untuk menguji hubungan antar variabel dengan menggunakan uji chi-square. Analisis multivriat digunakan untuk menguji secara bersama sama antar variabel dengan menggunakan uji regresi logistic.

\section{HASIL DAN PEMBAHASAN}

\section{Karakteristik Responden}

Responden penelitian ini berjumlah 350 pria beresiko. Karakteristik responden meliputi umur, tingkat pendidikan, pendapatan, pekerjaan dan status perkawinan (Tabel 1). Umur responden terbanyak adalah kelompok dewasa tua (>35 tahun) yaitu $(50,6 \%)$ dengan rata-rata umur responden dalam penelitian ini 39 tahun. Umur responden termuda adalah 18 tahun dan usia tertua adalah 51 tahun.

Sebagian besar responden berada pada kelompok pendidikan lanjutan (SMA dan PT) yaitu sebanyak $52 \%$, dengan pendidikan terendah SD dan pendidikan tertinggi SMA. Sebagian besar responden berada pada kelompok pendapatan Menengah Keatas. Sebagian besar responden berada pada kelompok kawin. Sebagian besar responden berada pada kelompok Pekerjaan dengan Mobilitas Tinggi (Mobile).

Tabel 1. Karakteristik Responden dan hubungan dengan persepsi tentang kondom

\begin{tabular}{lccc}
\hline Karakteristik Responden & Frekuensi (f) & $\begin{array}{c}\text { Persetase } \\
(\boldsymbol{\%})\end{array}$ & Nilai p \\
\hline Umur & & & 0.00 \\
$\bullet \quad$ Dewasa Tua ( > 35 tahun ) & 177 & 50,6 & \\
- Dewasa Muda (<35 Tahun) & 173 & 49,4 & \\
Tingkat Pendidikan & & & 0.00 \\
- Pendidikan lanjutan ( SMA dan & 182 & 52,0 & \\
$\quad$ PT) & 168 & 48,0 & \\
- Pendidikan dasar ( SD dan SMP) & & & \\
Pendapatan & & & 0.00 \\
• Menengah Keatas ( $\geq 1.500 .000)$ & 251 & 71.7 & \\
• Menengah KeBawah (<1.500.000) & 99 & 28.3 & \multirow{2}{*}{0.121} \\
Pekerjaan & & & \\
\hline
\end{tabular}


- Mobile

- Semi Mobile

Status Perkawinan

- Kawin

- Belum Kawin
170

180

264

86
48,6

51,4

75,4

24,6

Sumber : Data Primer, diolah pada tahun 2014

Pada analisis bivariat penelitian ini menyebutkan bahwa ada hubungan antara umur dengan persepsi kondom pada kalangan pria beresiko di Malang dengan nilai Asymp. Sig. $0,00 \quad(\mathrm{p}<0,05)$ selain itu berdasarkan analisis bivariat menunjukkan bahwa responden yang berpersepsi negatif tentang kondom lebih banyak terdapat pada kelompok umur dewasa muda ( $<35$ tahun) sebanyak $58.5 \%$ dibandingkan yang pada kelompok umur dewasa tua ( $\geq 35$ tahun) yaitu sebanyak (38.0\%). Hal tersebut disebakan karena kebutuhan dan kecenderungan berubah seiring dengan bertambahnya umur seseorang dan hal tersebut tentu akan mempengaruhi pola pikir, pengalaman dan persepsi seseorang dengan asumsi bahwa semakin bertambah usia maka seseorang akan mendapatkan pengalaman yang lebih banyak dibandingkan dengan usia di bawahnya. Dalam hal ini dengan usia dewasa muda (<35 tahun) cenderung akan mempunyai persepsi negatif tentang kondom dikarenakan persepsi dibentuk oleh salah satunya adalah pengalaman, dengan pengalaman yang baik tentang kondom maka akan cenderung untuk berpersepsi positif tentang kondom. Selain itu orang akan cederung mempunyai persamaan dengan yang seumur dengan mereka, sehingga dapat disimpulkan bahwa perbedaan umur akan menyebabkan perbedaan dari perilaku, persepsi atau cara pandang dan cara memperoleh serta mengambil keputusan. Hal ini juga sesuai dengan teori Health Belief Models, persepsi seseorang dipengaruhi oleh faktor sosiodemografi termasuk umur yang secara tidak langsung dapat mempengaruhi perilaku pencegahan (Mutmainah, 1997).

Tingkat Pendidikan responden dapat dikatakan tergolong cukup tinggi karena sebagian besar responden berada pada kelompok pendidikan menengah keatas (SMA dan PT) yaitu sebanyak 51.1\%. Dengan pendidikan terendah SD dan pendidikan tertinggi SMA. Hal ini tidak jauh beda dengan hasil STBP 2011 dimana tingkat pendidikan Pria Beresiko tinggi di sebanyak $20 \%$ berpendidikan SMP dan $46 \%$ berpendidikan SMA dan hanya 7\% yang berpendidikan perguruan tinggi. Berdasarkan analisis bivariat dinyatakan bahwa ada hubungan antara pendidikan dengan persepsi kondom pada kalangan pria beresiko di 
Malang dengan nilai Asymp. Sig. 0,00 $(\mathrm{p}<0,05)$. Notoatmodjo (2007) yang menyatakan bahwa semakin tinggi tingkat pendidikan seseorang maka kemampuan untuk menyerap informasi/pesan kesehatan juga akan semakin baik. Tingkat pendidikan dipercayai mempunyai pengaruh tidak langsung terhadap perilaku dengan cara mempengaruhi persepsi Individu. Dengan pendidikan tinggi, cenderung memiliki perhatian yang besar terhadap kesehatannya sehingga jika individu tersebut mengalami gangguan kesehatan maka ia akan segera mencari pelayanan kesehatan

Sedangkan berdasarkan penelitian ini yang lebih banyak berpersepsi negatif tentang kondom adalah berpendidikan menengah keatas (SMA dan PT). Hal ini dapat disebabkan karena faktor yang lain misalnya lingkungan, seperti yang disebutkan di dalam teori Social Learning yang menyatakan bahwa perilaku dan lingkungan dalam suatu proses "deterministik resiprokal". Kalau lingkungan menentukan dan menyebabkan terjadinya perilaku kebanyakan, maka seorang individu menggunakan proses kognitifnya untuk menginterpretasikan lingkungan maupun perilaku yang dijalankannya serta memberikan rekasi dengan cara mengubah lingkungan dan menerima hasil perilaku yang lebih baik (48). Dengan kata lain dapat disimpulkan bahwa jika seseorang berada di dalam lingkungan yang memiliki persepsi positif maka kecenderungan untuk ikut berpersepsi positif akan lebih besar, begitu juga sebaliknya.

Pada penelitian ini diketahui bahwa sebagian besar responden berada pada kelompok pendapatan Menengah Keatas $(\geq 1.500 .000)$ yaitu sebanyak $71.7 \%$. Dengan pendapatan terendah 1.000 .000 , pendapatan tertinggi 24.000.000 dan rata-rata pendapatan 2.163.000.

Berdasarkan anaisis bivariat sebagian besar responden mempunyai pendapatan $\geq 1.500 .000$ (71.7\%). Berdasarkan analisis bivariat menunjukkan nilai Asymp. Sig. 0,121 ( $p>0,05)$ dapat disimpulkan bahwa tidak ada hubungan antara pendapatan responden dengan persepsi tentang kondom pada kalangan pria beresiko di Malang.

Rata-rata pendapatan yang cukup tinggi membuat responden cenderung untuk berperilaku beresiko dibandingkan dengan yang berpenghasilan rendah. Dengan pendapatan yang cukup, maka seseorang akan merasa mampu untuk memperoleh sesuatu dalam hal ini dikaitkan dengan membeli seks. Tetapi lebih sering bahwa perilaku tersebut tidak disertai dengan perilaku pencegahan infeksi seperti penggunaan kondom. Seperti data STBP tahun 2011 menunjukkan bahwa penggunaan 
kondom pada seks terakhir pada kalangan pria beresiko hanya sekitar $14 \%$ bahkan dari data laporan SSP menyebutkan bahwa penggunaan kondom pada kalangan tersebut hanya sekitar 10\%. Sedangkan $55.6 \%$ mengaku pernah membeli seks pada satu tahun terakhir (STBP, 2011). Hal tersebut dapat disebabkan karena dengan pendapatan yang cukup tinggi dan kemampuan untuk membeli seks mereka akan merasa rugi jika melakukan hubungan seksual yang telah dibeli tetapi harus menggunakan kondom pada saat berhubungan seksual.

Dalam penelitian ini responden diambil dari 4 jenis pekerjaan yang dianggap merupakan pekerjaan yang berada di dalam lingkungan yang beresiko tinggi. Diketahui bahwa sebagian besar responden berada pada kelompok Pekerjaan dengan Mobilitas Tinggi (Mobile) sebesar $48.6 \%$ dengan jumlah supir truk sebanyak 85 orang dan jumlah supir taksi 85 orang. Sedangkan sebagian kecil pada kelompok Mobilitas yang cukup tinggi (Semi Mobile) yaitu sebanyak $51.4 \%$ yang terdiri dari buruh pabrik 80 orang dan jumlah nelayan 100 orang. Berdasarkan analisis bivariat menunjukkan bahwa responden paling banyak berpersepsi negatif tentang kondom adalah dari kalangan Semi Mobile yang terdiri dari nelayan dan buruh pabrik (67.2\%) dan yang paling banyak berpersepsi positif 182 tentang kondom adalah di kalangan pekerjaan Mobile yang terdiri dari supir taksi dan supir truk (72.4\%). Sedangkan dari analisis multivariat menunjukkan bahwa pekerjaan juga memberikan pengaruh terhadap persepsi kondom pada kalangan pria beresiko dengan OR sebesar 1.325.

Pada kalangan supir truk yang mempunyai persepsi positif cukup tinggi yaitu sebanyak 15.4\%. Hal ini dapat disebabkan karena pada kalangan supir truk lebih banyak menjadi target dari program pemerintah tentang pencegahan HIV/AIDS karena tingkat penyebaran di kalangan ini cukup tinggi. Berdasarkan dari data KPAN menyebutkan bahwa pengidap HIV dari kalangan supir truk meningkat setiap tahunnya. Selain itu supir truk sebagai salah satu pekerjaan di sector transportasi mempunyai tingkat mobilitas yang lebih tinggi dibandingkan dengan pekerjaan yang lain, sehingga tingkat sosialisasinya juga semakin tinggi sehingga pertukaran informasi dan pengalaman juga semakin meningkat di kalangan mereka.

Cukup banyak literatur yang membahas hubungan antara pekerja sektor transportasi terutama pengemudi truk terhadap penyebaran HIV-AIDS. Selain itu LSM yang bekerja di Jawa Timur yang meneliti pengemudi truk melaporkan tingginya perilaku seksual dan mereka 
berusaha melakukan kampanye informasi termasuk dengan menggunakan metode pengecatan truk. Hasil juga menyebutkan bahwa di kalangan supir truk sebanyak $8.8 \%$ masih mempunyai persepsi negatif tentang kondom. Meskipun telah banyak kampanye atau intervensi yang dilakukan pada kalangan supir truk tetapi masih ada yang berpersepsi negatif tentang kondom. Banyak faktor lain yang menyebabkan hal ini terjadi, seperti akses informasi dan kurangnya sosialisasi oleh petugas kesehatan juga dapat menjadi salah satu faktor. Faktor lain seperti yang disebutkan di dalam penelitian yang dilakukan oleh Chantanavich pada tahun 2000 di beberapa kota di Asia Tenggara menyebutkan bahwa alasan para pekerja di sektor transportasi sering menggunakan PSK tanpa kondom yaitu karena tingkat pendapatan yang tinggi serta jauh dari keluarga. Selain itu survey yang dilakukan oleh ILO pada tahun 2011 menyebutkan bahwa tingkat penggunaan kondom konsisten pada seks terakhir di kalangan supir truk kurang dari $10 \%$. Hal ini dapat terjadi karena persepsi negatif yang masih dimiliki oleh para supir truk ditunjang dengan faktor yang lainnya menyebabkan mereka enggan untuk menggunakan kondom.

Sedangkan sebagian besar yang berpersepsi negatif tentang kondom adalah pada kalangan buruh pabrik yaitu sebesar
20\%. Buruh pabrik merupakan salah satu pekerjaan yang beresiko tinggi terhadap infeksi HIV karena sering berpisah dengan keluarga. Penelitian yang dilakukan oleh ILO menunjukan buruh pabrik di Jakarta yang kebanyakan migran dari daerah pedesaan yang tidak tnggal bersama keluarga mereka. Persepsi negatif lebih banyak pada kalangan buruh pabrik yaitu sebanyak 70 dari 80 orang responden, hal ini disebabkan karena buruh pabrik mempunyai pola waktu di dalam bekerja, mereka hanya diberikan waktu istirahat selama 1 jam dengan total bekerja 8-10 jam. Akses informasi yang sangat minim, kurangnya sosialisasi dari petugas kesehatan dan kurangnya perhatian dari pihak perusahaan untuk lebih memberikan informasi tentang kesehatan kepada karyawannya dapat menyebabkan persepsi yang dimiliki menjadi negatif.

Pada kalangan nelayan jumlah antara yang mempunyai persepsi positif dan negatif hampir sama prosentasenya yaitu $14.0 \%$ dan $14.6 \%$. Persepsi negatif yang mereka miliki lebih banyak disebabkan oleh kurangnya akses informasi dan sosialisasi dari petugas kesehatan. Selain itu miskonsepsi tentang tata cara pencegahan OMS dan HIV-AIDS merupakan penyebab dari persepsi negatif tersebut. Mereka percaya bahwa kondom bukan satu satunya alat yang dapat mencegah penularan HIV tetapi dengan cara meminum 
antibiotic sebelum melakukan hubungan seksual, minum jamu dan mencuci alat kelamin merka yakin bahwa tidak akan tertular.

Nelayan merupakan salah satu pekerjaan yang rentan untuk tertular HIV. Nelayan lebih banyak menghabiskan waktu jauh dari keluarga dan seringnya singgah di pelabuhan menyebabkan mereka mempunyai kesempatan untuk bertemu dengan PSK, apalagi jarak lokalisasi dengan pelabuhan cukup dekat hanya sekitar $2 \mathrm{~km}$. jika nelayan terinfeksi, maka hal tersebut tidak hanya menularkan pada keluaarganya tetapi juga pada tempat tempat yang mereka singgahi setelahnya. Menurut ILO lebih dari 200.000 kepala keluarga menggantungkan hidupnya sebagai nelayan, dan kurang dari seperempatnya merupakan kelompok beresiko terinfeksi HIV. Mereka melakukan kegiatan beresiko tanpa menggunakan kondom tetapi pencegahan yang dilakukan dengan cara meminum obat-obatan dosis tinggi.kebanyakan nelayan pernah singgah di beberapa tempat di Indonesia dan memuaskan hasrat seksnya dengan cepat dan hal ini bagi mereka merupakan hal yang wajar. Selain di lokalisasi. PSK juga dapat dihubungin melalui kios-kios dan warung yang berada dekat dengan tempat yang mereka singgahi (Hogo, 2001).
Sebagian besar responden (75.4\%) berstatus sudah kawin dan sebanyak $24.5 \%$ belum menikah. Sedangkan berdasarkan analisis bivariat menunjukkan bahwa responden yang statusnya belum kawin lebih banyak berpersepsi positif tentang kondom (86.1\%) dibandingkan dengan responden yang sudah kawin (35.6\%). Hasil uji memberikan nilai Asymp. Sig. 0,00 ( $<<0,05)$ sehingga dapat disimpulkan bahwa ada hubungan antara status perkawinan responden dengan persepsi tentang kondom pada pria beresiko di Malang Tahun 2014.

Dari hasil uji multivariat tersebut, satus perkawinan memberikan pengaruh paling besar dengan OR 6.330 kali, Pria beresiko dengan status perkawinan sudah kawin akan mempunyai persepsi positif tentang kondom lebih besar 6.330 kali lebih besar dibandingkan dengan yang belum kawin. Hal tersebut dapat disebabkan karena dengan status yang sudah kawin akan lebih mudah mendapatkan akses informasi tentang penggunaan kondom daripada yang belum kawin selain itu dapat leluasa untuk datang ke tenaga kesehatan untuk memperoleh penjelasan tentang kondom, sehingga informasi yang diperolehnya akan cenderung membentuk persepsi yang positif tentang kondom. Sedangkan yang belum kawin akan cenderung untuk memperoleh informasi secara sembunyi-sembunyi dan tidak 
diketahui apakah informasi yang Hal inilah yang menyebabkan persepsi yang diperolehnya adalah informasi yang benar. dimilikinya cenderung negative.

\section{Faktor Eksternal Yang Mempengaruhi Persepsi tentang Kondom}

Tabel 2. Faktor Eksternal dan hubungan dengan persepsi tentang kondom

\begin{tabular}{|c|c|c|c|}
\hline Variabel & Frekuensi (f) & $\begin{array}{c}\text { Persetase } \\
(\%)\end{array}$ & Nilai $p$ \\
\hline $\begin{array}{l}\text { Pengetahuan tentang Kondom } \\
\text { - Baik } \\
\text { - Kurang }\end{array}$ & $\begin{array}{l}241 \\
109\end{array}$ & $\begin{array}{l}68,9 \\
31,1\end{array}$ & 0.443 \\
\hline $\begin{array}{l}\text { Pengalaman Tentang Kondom } \\
\text { - Baik } \\
\text { - Kurang }\end{array}$ & $\begin{array}{c}199 \\
151\end{array}$ & $\begin{array}{l}56,9 \\
43,1\end{array}$ & 0.00 \\
\hline $\begin{array}{l}\text { Sikap terhadap kondom } \\
\text { - Baik } \\
\text { - Kurang }\end{array}$ & $\begin{array}{l}176 \\
174\end{array}$ & $\begin{array}{l}50.3 \\
49.7\end{array}$ & 0.00 \\
\hline $\begin{array}{l}\text { Media Informasi } \\
\text { - Positif } \\
\text { - Negatif }\end{array}$ & $\begin{array}{l}186 \\
164\end{array}$ & $\begin{array}{l}53,1 \\
46,9\end{array}$ & 0.016 \\
\hline $\begin{array}{l}\text { Pengalaman Orang Lain } \\
\text { - Baik } \\
\text { - Kurang }\end{array}$ & $\begin{array}{l}182 \\
168\end{array}$ & $\begin{array}{l}52,0 \\
48,0\end{array}$ & 0.001 \\
\hline $\begin{array}{l}\text { Sosialisasi Petugas Kesehatan } \\
\text { - Baik } \\
\text { - Kurang }\end{array}$ & $\begin{array}{l}192 \\
158\end{array}$ & $\begin{array}{l}54.9 \\
45.1\end{array}$ & 0.00 \\
\hline
\end{tabular}

Tabel 3. Hasil Analisis Multivariat Regresi Logistik Persepsi tentang kondom pada kalangan pria beresiko di Malang Tahun 2014

\begin{tabular}{|c|c|c|c|c|c|}
\hline No & $\begin{array}{c}\text { Variabel terpilih } \\
\text { dalam model }\end{array}$ & Wald & Nilai-p & OR & $95 \% \mathrm{CI}$ \\
\hline 1 & Pekerjaan & 7.286 & 0.007 & 1.325 & $1.080-1.626$ \\
\hline \multirow[t]{3}{*}{2} & Pengalaman & & & & \\
\hline & Responden & 4.211 & 0.040 & 1.793 & $1.027-3.133$ \\
\hline & Tentang Kondom & & & & \\
\hline 3 & Status Perkawinan & 22.4442 & 0.00 & 6.330 & $2.950-13.583$ \\
\hline
\end{tabular}

Faktor Yang Mempengaruhi Persepsi Kondom Pada Kalangan Pria Beresiko
Persepsi tentang kondom dalam penelitian ini adalah penafsiran/pemikiran seseorang yang berkaitan dengan 
penggunaan kondom dalam pencegahan penyakit menular seksual dan HIV-AIDS. Berdasarkan data kuantitatif penelitian ini diketahui bahwa $48 \%$ responden memiliki persepsi negatif tentang kondom. Hal ini dapat diketahui dari anggapan-anggapan yang menyatakan bahwa kondom dapat mengurangi kenikmatan ketika berhubungan seksual baik yang dirasakan sendiri maupun dari pasangan seks, selain itu menggunakan kondom dianggap sebagai sesuatu hal yang merepotkan. Kondom juga dianggap sebagai salah satu pelegalan seks bebas di masyarakat, selain itu juga masih ada yang beranggapan bahwa jika menggunakan kondom, maka akan dianggap orang berpenyakit. Pengetahuan yang kurang juga bisa menjadi penyebab masih banyaknya responden yang bepersepsi negatif tentang kondom. Dan persesi negatif yang akan menghambat seseorang untuk tidak menggunakan kondom.

Hal ini sejalan dengan penelitian yang dilakukan oleh Linda Mayarni Sirait (2012), berdasarkan penelitiannya yang dilakukan pada 95 anak buah kapal, didapatkan bahwa proporsi penggunaan kondom masih rendah, yaitu $23.2 \%$ dan berdasarkan hasil penelitian yang dilakukan didapatkan bahwa faktor yang paling dominan berpengaruh adalah persepsi. Semakin seseorang mempunyai persepsi positif tentang kondom maka akan cenderung unuk meningkatkan penggunaan kondom dalam mencegah penularan penyakit menular seksual dan HIV-AIDS

Berdasarkan analisis bivariat yang telah dilakukan ada 8 variabel yang berhubungan dengan persepsi kondom pada kalangan pria beresiko di malang tahun 2014 yaitu diketahui bahwa dari 11 variabel yang diteliti, terdapat 8 variabel yang berhubungan secara statistik dengan persepsi tentang kondom, yaitu variabel umur, pendidikan, pekerjaan, status perkawinan, pengalaman responden tentang kondom, sikap responden terhadap kondom,media informasi, pengalaman orang lain tentang kondom dan sosialisasi petugas kesehatan. Sedangkan dari hasil multivariat ada 3 variabel yang berhubungan erat dengan persepsi kondom pada kalangan pria beresiko di Malang yaitu variabel pekerjaa, pengalaman responden tentang penggunaan kondom dan status perkawinan.

Dari hasil uji multivariat tersebut, satus perkawinan memberikan pengaruh paling besar dengan OR 6.330 kali, Pria beresiko dengan status perkawinan sudah kawin akan mempunyai persepsi positif tentang kondom lebih besar 6.330kali lebih besar dibandingkan dengan yang belum kawin. Hal tersebut dapat disebabkan karena dengan status yang sudah kawin akan lebih mudah mendapatkan akses informasi tentang 
penggunaan kondom daripada yang belum kawin selain itu dapat leluasa untuk datang ke tenaga kesehatan untuk memperoleh penjelasan tentang kondom, sehingga informasi yang diperolehnya akan cenderung membentuk persepsi yang positif tentang kondom. Sedangkan yang belum kawin akan cenderung untuk memperoleh informasi secara sembunyi-sembunyi dan tidak diketahui apakah informasi yang diperolehnya adalah informasi yang benar. Hal inilah yang menyebabkan persepsi yang dimilikinya cenderung negatif.

Pengalaman tentang penggunaan kondom juga memberikan pengaruh terhadap persepsi kondom pada kalangan pria beresiko dengan OR sebesar 1.793 .Artinya bahwa pria beresiko dengan pengalaman yang baik tentang kondom akan mempunyai persepsi positif 1.793 kali lebih besar daripada yang mempunyai pengalaman kurang tentang kondom. Hal ini disebabkan karena persepsi salah satunya dibentuk berdasarkan pengalaman masa lalu yang dihasilkan dari pancaindra. Bagaimana cara individu untuk menginterpretasikan atau bereaksi terhadap stimulus tergantung pada pengalaman masa lalunya (Mutmainah, 1997).

Pekerjaan juga memberikan pengaruh terhadap persepsi kondom pada kalangan pria beresiko dengan OR sebesar 1.325. dari keempat pekerjaan yang terdapat dalam penelitian ini yaitu supir truk, supir taksi, buruh pabrik dan nelayan. responden paling banyak berpersepsi negatif tentang kondom adalah dari kalangan Semi Mobile yang terdiri dari nelayan dan buruh pabrik (67.2\%) dan yang paling banyak berpersepsi positif tentang kondom adalah di kalangan pekerjaan Mobile yang terdiri dari supir taksi dan supir truk (72.4\%). Di kalangan supir taksi akses informasi yang mudah dijangkau, kebisaaan membaca koran atau buku di pangkalan serta seringnya mereka saling berdiskusi ketika berkumpul bersama menyebabkan persepsi yang mereka miliki lebih positif dibandingkan dengan kalangan pada pekerjaan yang lain.

Sebagian besar yang berpersepsi negatif tentang kondom adalah pada kalangan buruh pabrik dan nelayan. Buruh pabrik merupakan salah satu pekerjaan yang beresiko tinggi terhadap infeksi HIV karena sering berpisah dengan keluarga. Penelitian yang dilakukan oleh ILO menunjukan buruh pabrik di Jakarta yang kebanyakan migran dari daerah pedesaan yang tidak tnggal bersama keluarga mereka. Persepsi negatif lebih banyak pada kalangan buruh pabrik yaitu sebanyak 70 dari 80 orang responden, hal ini disebabkan karena buruh pabrik mempunyai pola waktu di dalam bekerja, mereka hanya diberikan waktu istirahat selama 1 jam dengan total bekerja 8-10 jam. 
Akses informasi yang sangat minim, kurangnya sosialisasi dari petugas kesehatan dan kurangnya perhatian dari pihak perusahaan untuk lebih memberikan informasi tentang kesehatan kepada karyawannya dapat menyebabkan persepsi yang dimiliki menjadi negatif.

Persepsi negatif yang mereka miliki oleh nelayan lebih banyak disebabkan oleh kurangnya akses informasi dan sosialisasi dari petugas kesehatan. selain itu miskonsepsi tentang tata cara pencegahan OMS dan HIV-AIDS merupakan penyebab dari persepsi negatif tersebut. Mereka percaya bahwa kondom bukan satu satunya alat yang dapat mencegah penularan HIV tetapi dengan cara meminum antibiotic sebelum melakukan hubungan seksual, minum jamu dan mencuci alat kelamin merka yakin bahwa tidak akan tertular.

Nelayan merupakan salah satu pekerjaan yang rentan untuk tertular HIV. Nelayan lebih banyak menghabiskan waktu jauh dari keluarga dan seringnya singgah di pelabuhan menyebabkan mereka mempunyai kesempatan untuk bertemu dengan PSK, apalagi jarak lokalisasi dengan pelabuhan cukup dekat hanya sekitar $2 \mathrm{~km}$. jika nelayan terinfeksi, maka hal tersebut tidak hanya menularkan pada keluaarganya tetapi juga pada tempat tempat yang mereka singgahi setelahnya. Menurut ILO lebih dari 200.000 188 kepala keluarga menggantungkan hidupnya sebagai nelayan, dan kurang dari seperempatnya merupakan kelompok beresiko terinfeksi HIV. Mereka melakukan kegiatan beresiko tanpa menggunakan kondom tetapi pencegahan yang dilakukan dengan cara meminum obat-obatan dosis tinggi.kebanyakan nelayan pernah singgah di beberapa tempat di Indonesia dan memuaskan hasrat seksnya dengan cepat dan hal ini bagi mereka merupakan hal yang wajar. Selain di lokalisasi. PSK juga dapat dihubungin melalui kios-kios dan warung yang berada dekat dengan tempat yang mereka singgahi (Hogo, 2001).

Sedangkan yang mempunyai persepsi positif adalah jenis pekerjaan supir truk. Hal ini dapat disebabkan karena pada kalangan supir truk lebih banyak menjadi target dari program pemerintah tentang pencegahan HIV/AIDS karena tingkat penyebaran di kalangan ini cukup tinggi. Berdasarkan dari data KPAN menyebutkan bahwa pengidap HIV dari kalangan supir truk meningkat setiap tahunnya.

\section{SIMPULAN}

Hasil penelitian yaitu 11 variabel yang diteliti, terdapat 8 variabel yang berhubungan secara statistik dengan persepsi tentang kondom, yaitu variabel umur, pendidikan, pekerjaan, status perkawinan, pengalaman 
responden tentang kondom, sikap responden terhadap kondom, media informasi, pengalaman orang lain tentang kondom dan sosialisasi petugas kesehatan. Berdasarkan hasil uji multivariat menyatakan bahwa faktor paling berpengaruh adalah status perkawinan. KPA kabupaten dan Kota Malang hendaknya menyediakan informasi rinci dan mudah dijangkau tentang kondom bagi kaum lelaki yang beresiko termasuk demonstrasi penggunaannya.

\section{KEPUSTAKAAN}

Aaron, J.S. Condoms "Contains Worms" and "Cause HIV" in Tanzania: Negative Condom Beliefs Scale development and implications for HIV prevention. Sosial Science \& Medicine. 2012

Apriani, Fajar. Persepsi Masyarakat Kota Samarinda Mengenai Rencana Pemberlakuan Peraturan Daerah Tentang Pemakaian Kondom Sebagai Upaya Pencegahan Dan Penanggulangan HIV-AIDS. Fisip Universitas Mulawarman. Samarinda, 2011.

Ardana, K. Perilaku Keorganisasian. Graha IImu. Denpasar, 2008.

Ardiningsih, N. Stigma Kondom dan Ancaman HIVIAIDS. Pelita. Jakarta, 2013.

Bandura, A. Social Learning Theory. Englewood Cliffs, NJ.Prentice Hall. 1977.
Dinas Kesehatan (Dinkes) Kota dan kabupaten Malang. Malang Jawa Timur, 2013.

Hogo, G. Mobilitas Penduduk Dan HIV-AIDS Di Indonesia. UNDP South East Asia HIV Development Office. Jakarta, 2001.

ILO. Buletin Pekerja Migrant dan HIV-AIDS. ILO. Jakarta, 2007

ILO. Child Labor. A Text Book For University Student. ILO. Genewa, 2004.

Indonesia Aids Coalition. Data final STBP 2011, Sub-dit HIV-PMS Departemen Kesehatan Republik Indonesia. Jakarta, 2011.

Indonesia Aids Coalition. Data final STBP 2007. Sub-dit HIV-PMS Departemen Kesehatan Republik Indonesia. Jakarta, 2007.

Komisi Penanggulangan AIDS. Perkembangan Situasi Epidemi HIVAIDS. KPAN. Jakarta, 2013.

Mudiharno. Perilaku Seksual Beresiko Tertular PMS dan HIVIAIDS, Kasus Supir Truk Antar Propinsi. Pusat Penelitian Kependudukan Universitas Gadjah Mada. Yogyakarta, 1999.

Mutmainah. Psikologi Komunikasi. Universitas Terbuka. Jakarta, 1997.

Sirait, L.M. Hubungan Komponen Health Belief Model ( $\mathrm{Hbm})$ Dengan Tindakan Penggunaan Kondom Pada Anak Buah Kapal (Abk) Di Pelabuhan Belawan Tahun. Universitas Sumatera Utara. Medan, 2012 
Jurnal Promosi Kesehatan Indonesia Vol. 12 / No. 2 Agustus 2017

Sutiyarsih, T. Perilaku pemakaian kondom pengemudi truk dalam upaya pencegahan HIV dan AIDS dan faktor- faktor yang mempengaruhinya, di Kabupaten Batang. PKIP FKM Undip Semarang, 2010. 